\title{
Genetic diversity of Cyprinion macrostomus (Heckel, 1843) populations in the Euphrates and Tigris rivers based on partial cytochrome b sequences of mitochondrial DNA
}

\author{
ARIF PARMAKSIZ \\ Harran University, Faculty of Science and Art, Department of Biology, Sanlurfa - 63100, Turkey \\ e-mail:aprmksz@gmail.com
}

\section{ABSTRACT}

\begin{abstract}
Cyprinion macrostomus (Heckel, 1843), thriving in both Euphrates and Tigris river systems, is an economically important food fish species of the family Cyprinidae. It is important to know genetic structure of fish populations in terms of identification of genetic structure of stocks for facilitating sustainable fishing and conservation strategies. The present study, evaluated genetic structure of $C$. macrostomus populations in Euphrates and Tigris rivers using mtDNA cytochrome b sequence analysis. A total number of 44 C. macrostomus specimens were collected from Euphrates and Tigris rivers and total DNA was isolated from muscle tissue. Approximately $600 \mathrm{bp}$ of mtDNA cyt $\mathrm{b}$ site was amplified by PCR and 8 polymorphic and 8 haplotypes were identified after sequence analysis. Mean haplotype and nucleotide diversity were calculated as 0.738 and 0.00253 respectively. Both populations had similar values in terms of haplotype as well as nucleotide diversity and neutrality tests were also found to be statistically insignificant.
\end{abstract}

Keywords: Cyprinion macrostomus, Euphrates River, Genetic diversity, mtDNA cyt b, Tigris River

The freshwater fish family Cyprinidae is the most important family in the Euphrates and Tigris river systems. Cyprinion macrostomus (Heckel, 1843) belongs to the family Cyprinidae with distribution in Turkey, Syria, Iraq and Iran (Kelle, 1978; Kuru, 1980; Tays1, 2014; Bilici et al., 2015; Uckun et al., 2015). C. macrostomus is an edible species and also valuable for sport fishing (Abdoli, 2000). This species also plays a therapeutic role in medical treatment (Undar et al., 1990). Several workers carried out research on various aspects of the species viz., morphological characteristics (Unlu, 1999), karyotype analysis (Gaffaroglu and Yuksel, 2004), age determination (Aydın et al., 2009), haematology (Duman and Sahan 2014), length-weight relationships (Sedaghat and Hoseini, 2012; Bibak et al., 2013), phylogeographical and phylogenetic relationships between C. macrostomus, C. kais and Carasobarbus chantrei in Euphrates and Tigris rivers (Durna et al., 2012), selected morphometric characteristics (Kara and Gunes, 2015) and morphological differences (Bilici et al., 2015).

For fishery management and conservation of fish species having economic importance, it is critical to understand genetic diversity and population structure (Ward, 2000; Ortega et al., 2006). Mitochondrial DNA (mtDNA), which is an important and common molecular marker, has been widely used for estimating molecular variability and genetic structure of populations of numerous organisms (Xu et al., 2011). Recently, the mtDNA study has become more popular due to the advancement of molecular techniques for DNA sequencing and data analysis (Liu and Zhou, 2016). Among various mitochondrial genes, variation of ytochrome b (cyt b) gene has been used for population studies in cyprinids (Fayazi et al., 2006).

The present study was undertaken to determine genetic diversity of C. macrostomus populations in the Euphrates and Tigris river systems, by sequence analysis of mtDNA cyt $b$ gene.

The fish samples used in our study were collected from two different localities viz., Adryaman and Diyarbakır of Euphrates and Tigris river systems respectively, between February 2014 and January 2015. The samples were placed in ice container immediately after sampling and transported to the Zoology Laboratory of the Department of Biology, Faculty of Science and Arts, Harran University. Individuals were chosen randomly among the specimens which were decided to be the target species following identification. About $200 \mathrm{mg}$ each of muscle tissue was dissected from a part closer to dorsal fin of the fish samples and placed in the microcentrifuge tubes containing $95 \%$ ethanol and kept at $-20^{\circ} \mathrm{C}$ until DNA extraction. Total DNA was isolated using commercial kit (GeneJET Genomic DNA Purification Kit, Thermo Scientific). Five microliters each of the isolated DNA 
samples were run in $1 \%$ agarose gel at $100 \mathrm{~V}$ for $40 \mathrm{~min}$, and results were examined.

Primers (Briolay et al., 1998) used for amplification of mtDNA cyt $b$ gene in the present study were :

\section{L15267: 5'-AATGACTTGAAGAACCACCGT-3'}

\section{H15891: 5'-GTTTGATCCCGTTTCGTGTA-3'}

Polymerase chain reactions (PCR) were performed at a total volume of $25 \mu \mathrm{l}$ comprising $0.5 \mathrm{mM}$ of each primer, $0.2 \mathrm{mM}$ of each dNTP, 1xPCR buffer, $2.5 \mathrm{mM} \mathrm{MgCl}_{2}$, 1 unit Taq polymerase and approximately $90 \mathrm{ng}$ of template DNA. PCR amplification was carried out in a BIO-RAD T100 ${ }^{\mathrm{TM}}$ Thermal Cycler under the following conditions in a total number of 35 cycles: 3 min initial denaturation at $95^{\circ} \mathrm{C}$, denaturation at $95^{\circ} \mathrm{C}$ for $30 \mathrm{~s}$, annealing at $51^{\circ} \mathrm{C}$ for $30 \mathrm{~s}$, extension at $72^{\circ} \mathrm{C}$ for $45 \mathrm{~s}$, a final extension at $72^{\circ} \mathrm{C}$ for $10 \mathrm{~min}$ and terminated keeping the PCR products at $72^{\circ} \mathrm{C}$ for $5 \mathrm{~s}$. PCR products ( $3 \mu \mathrm{l}$ each) were analysed on $2 \%$ agarose gel (1x TAE) together with a ladder and the most specific products were selected for sequencing. Amplified PCR products were purified using Favor/Prep gel/PCR purification mini kit (Favorgen, Vienna, Austria). Sequencing was done with an automated DNA sequencer (3500 XL Genetic Analyser, Thermo Fisher Scientific).

mtDNA cyt b sequences were evaluated and converted into FASTA format using Chromas Pro v 2.0.1 software (http://www.technelysium.com.au/ChromasPro. html). Resulting sequences of all individuals in FASTA format were aligned using BioEdit software version 7.2.5.

The number of polymorphic sites and haplotypes, diversity of haplotypes and nucleotides, Tajima D and Fu's statistics were esimated for the populations using DnaSP5.10.01 program. The phylogenetic relationships between haplotypes were identified using Network version 5.0 software.
An average number of $600 \mathrm{bp}$ fragments of mtDNA cyt b gene were sequenced from $44 C$. macrostomus specimens; totally 8 polymorphic sites and 8 haplotypes were identified. Nucleotide variations of this region are shown in Table 1. Haplotype diversity (Hd), the nucleotide diversity $(\pi)$ and the neutrality tests for each of the populations are given in Table 2 .

Diyarbakır population had greater values in terms of both haplotype diversity $(\mathrm{Hd}=0.738)$ and nucleotide diversity ( $\pi=0.00253)$. Tajima's D and Fu's Fs values, on the other hand, were negative for both the populations. Haplotypes $\mathrm{H} 1, \mathrm{H} 2$ and $\mathrm{H} 4$ were common for two populations, while $\mathrm{H} 3$ was found only in Adiyaman and H5, H6, H7 and H8 only in Diyarbakir. Haplotype H1 had a higher frequency which was observed in both populations.

Fig. 1 shows evolutionary network for 8 haplotypes identified on the Median-Joining Network (MJN) of haplotypes created for 44 samples analysed and resulting MJN shows presence of a central haplotype (H1) which indicates an evolutionary connection. Besides, it is possible to speculate that all of the other haplotypes were connected with haplotype H1.

\begin{tabular}{lllllllll}
\multicolumn{1}{l}{ Table 1. Haplotypes and nucleotide variations of mtDNA cyt b } \\
\hline Haplotypes & 7 & 1 & 2 & 3 & 3 & 3 & 3 & 4 \\
& 8 & 3 & 5 & 0 & 3 & 3 & 6 & 8 \\
& & 2 & 8 & 0 & 0 & 3 & 3 & 6 \\
\hline H1 & C & A & A & G & A & A & G & A \\
H2 &. &. &. & A &. &. &. &. \\
H3 &. &. & G &. &. &. &. &. \\
H4 &. &. &. &. &. &. & A &. \\
H5 &. & G &. &. &. & G &. &. \\
H6 &. &. &. & A & G &. &. &. \\
H7 &. &. &. &. &. &. &. & G \\
H8 & T & G &. &. &. &. &. &. \\
\hline
\end{tabular}

Table 2. C. macrostomus sampling site, size and their genetic diversity inferred from mtDNA cyt $\mathrm{b}$ gene sequence $(\mathrm{n}=$ Number of individuals, Nh: Number of haplotypes, Hd: Haplotype diversity, $\pi$ : Nucleotide diversity)

\begin{tabular}{|c|c|c|c|c|c|c|c|c|}
\hline River system & Locality & $\mathrm{n}$ & $\mathrm{Nh}$ & $\begin{array}{l}\text { Haplotype } \\
\text { frequency }\end{array}$ & $\mathrm{Hd}$ & $\pi$ & Tajima's D & Fu's Fs \\
\hline Euphrates River & Adiyaman & 17 & 4 & $\begin{array}{l}\text { H1 }(0.47) \\
\text { H2 }(0.41) \\
\text { H3 }(0.06) \\
\text { H4 (0.06) }\end{array}$ & 0.640 & 0.00130 & -0.43847 & -0.828 \\
\hline Tigris River & Diyarbakır & 27 & 7 & $\begin{array}{l}\text { H1 }(0.49) \\
\text { H2 }(0.07) \\
\text { H4 }(0.07) \\
\text { H5 (0.07) } \\
\text { H6 (0.04) } \\
\text { H7 (0.07) } \\
\text { H8 }(0.19)\end{array}$ & 0.738 & 0.00253 & -0.66327 & -1.718 \\
\hline
\end{tabular}




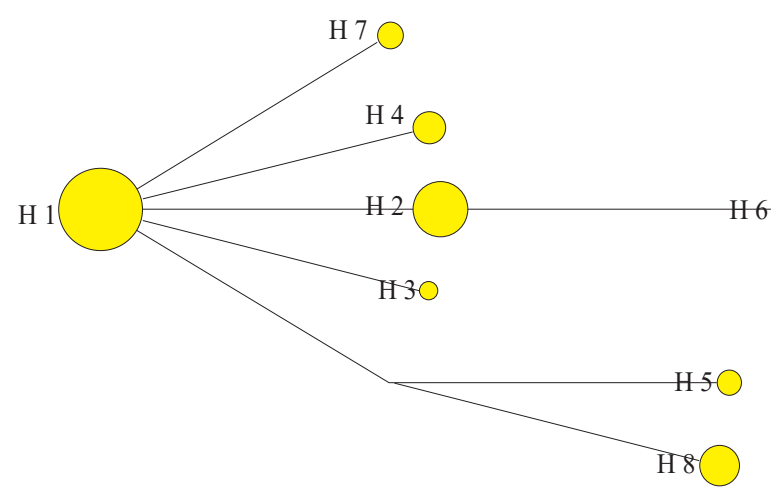

Fig. 1. Median-joining network showing relationships between 8 haplotypes of two $C$. macrostomus populations

Tajima's D and Fu' Fs tests were applied for each population. Tajima's D value was negative in bothAdiyaman (-0.43847) and Diyarbakır (-0.66327) populations, and it was also negative in total (-0.91457) which was found to be statistically insignificant ( $\mathrm{p}>0.05)$. Fu's tests were negative in Adiyaman (-0.828) as well as Diyarbakır (-1.718) populations which was also negative in total (-2.357) and found to be statistically insignificant $(\mathrm{p}>0.05)$.

Because Adiyaman Province is close to Euphrates and Diyarbakır Province to Tigris river, fishing activities are carried out by the people who live in these regions. C. macrostomus is one of the important fish species caught and consumed by local people as well as sold in the neighbouring provinces. Eight polymorphic sites and 8 haplotypes were identified from mtDNA cyt $b$ gene consisting of 600 base pairs on an average. Four haplotypes (H1, H2, H3 and H4) were observed in Adryaman population and 7 haplotypes $(\mathrm{H} 1, \mathrm{H} 2, \mathrm{H} 4, \mathrm{H} 5, \mathrm{H} 6, \mathrm{H} 7$ and H8) in Diyarbakır population. Haplotype H1 was seen in a total of 21 individuals and it appears that $\mathrm{H} 1$ is ancestral haplotype as it was found commonly in both populations and represented with the highest number of individuals. There are only two sequences of C. macrostomus species in GenBank (www.ncbi.nlm. nih.gov/genbank/) for the gene studied. As they were compared with haplotypes in the present study, they were identified to be Haplotype 2 (KP712263.1) and Haplotype 8 (AF180826.1). Thereby, haplotypes H1, H3, H4, H5, H6 and H7 were identified for the first time in this study. Mean haplotype diversity and nucleotide diversity were found to be 0.724 and 0.00221 , respectively. Diyarbakir population had higher values than Adiyaman population in terms of both haplotype diversity and nucleotide diversity.

Mean haplotype and nucleotide diversity values based on mtDNA sequence analysis have been reported for certain cyprinids living in Euphrates and Tigris river systems. The values determined by researchers in various fish speices are: Hd: $0.642 ; \pi: 0.00138$ in C. trutta populations (Parmaksiz and Eksi, 2017), Hd: 0.246 ; $\pi$ : 0.00045 in Barbus grypus populations (Parmaksiz et al., 2017) and $\mathrm{Hd}=0.538$ and $\pi=0.00345$ for Carasobarbus luteus populations (Eskici, 2017). The mean haplotype diversity estimated in this study (0.724) was the maximum compared to those reported for other species. The value of nucleotide diversity recorded in C. macrostomus during the present study was higher in comparison with B. grypus and C. trutta species, while, it was found to be lower as compared to $C$. luteus. Population size and environmental heterogeneity contribute towards high Hd values for populations (Nei, 1987; Avise, 1998). Lower nucleotide diversity values are also indicative of low genetic diversity and population diversity is influenced by many factors, such as bottleneck effects, anthropogenic activity and habitation (Fennando et al., 2000; Ma et al., 2010).

Fixation index $\left(\mathrm{F}_{\mathrm{ST}}\right)$ is used to determine the level of difference between two populations. In the present study, this value was calculated as $0.22724(\mathrm{p}<0.05)$ and the difference between Adıyaman and Diyarbakır populations was found to be statistically significant.

In median joining network analysis, haplotype $\mathrm{H} 1$ was in the center of the network and the dominant one. All the other haplotypes also consisted of H1 (Fig. 1). Haplotype H1 appears to be ancestral since it is common in both the populations and dominant.

Tajima's D and Fu's Fs were applied separately and totally for both populations. All values were insignificant ( $p>0.05$ ) for overall population indicating that a possible population change occurred in the past.

In addition, it was determined that either of mean Tajima's D and Fu's Fs values were negative in the study by Parmaksiz and Eksi (2017), on the contrary, both of them were positive in the study by Parmaksız and Eskici (2018). A positive Fu's Fs and Tajima's D test signifies lower levels for both low and high frequency polymorphisms, indicating a decrease in population size (Hu et al., 2016 ). Considering the values in the neutrality tests in this survey, a decrease was not observed in the populations studied.

Haplotypes identified for mtDNA cyt b locus created a data set which is important for identifying the genetic diversity of C. macrostomus species that thrives in Euphrates and Tigris rivers. The data generated represent a significant tool for the characterisation of separate 
populations for management and breeding programs. Further studies on a greater number of populations using diverse genetic markers will be more explanatory for assessing population genetics of this species.

\section{Acknowledgements}

This study was funded by Harran University Research Fund (HUBAK Project No: 17219).

\section{References}

Abdoli, A. 2000. The inland water fishes of Iran. $1^{\text {st }}$ edn. Iranian Museum of Nature and Wildlife, Tehran, Iran.

Avise, J. 1998. Phylogeography. Harvard University Press, Cambridge, MA, 102 pp.

Aydın, R., Sen, D., Calta, M. and Canpolat, O. 2009. Readability of Cyprinion macrostomus (Heckel, 1843) due to accumulation deposits of magnesium element in bone structures. Proceedings of the National Fisheries Symposium, Elazig, Turkey.

Bibak, M., Hoseini, S. A. and Izadpanahi, G. R. 2013. Lengthweight relationship of Cyprinion macrostomus (Heckel, 1843) in Dalaki River and Shahpur River in South of Iran. World J. Fish Mar. Sci., 5: 263-265. DOI: 10.5829/idosi. wjfms.2013.05.03.66185.

Bilici, S., Cicek, T., Baysal, A., Unlu, E. and Alp, A. 2015. Morphological differences among the Cyprinion macrostomus (Cyprinidae) populations in the Tigris River. J. Surv. Fish. Sci., 2(1): 57-67.

Briolay, J., Galtier, N., Brito, R. M. and Bouvet, Y. 1998. Molecular phylogeny of Cyprinidae inferred from cytochrome $b$ DNA sequences. Mol. Phylogenet. Evol. 9: 100-108. DOI: 10.1006/mpev.1997.0441

Duman, S. and Sahan, A. 2014. The identification of some hematological parameters and non-specific immune response in Cyprinion macrostomus (Heckel, 1843) living in Kangal (Sivas), Balıklı Cermik thermal hot spring and Topardıc Stream (Sivas). Yunus Res. Bull., (4): 21-28.

Durna, S., Bardakc1, F. and Deger, N. 2012. Genetic diversity of Cyprinion macrostomus (Heckel, 1843) (Teleostei:Cyprinidae) in Anatolia. Turk. J. Fish. Aquat. Sci., 12: 651- 659. DOI: 10.4194/1303-2712-v12 313.

Eskici, H. K. 2017. Determination of mtDNA genetic variation in Carasobarbus luteus (Heckel, 1843) populations. M. Sc. Thesis, Harran University, Sanliurfa, Turkey.

Fayazi, J., Moradi, M., Rahimi, G., Ashtyani, R. and Galledari, H. 2006. Genetic differentiation and phylogenetic relationships among Barbus xanthopterus (Cyprinidae) populations in south-west of Iran using mitochondrial DNA markers. Pak. J. Biol. Sci., 9: 2249-2254. DOI: 10.3923/ pjbs.2006.2249.2254

Fennando, P., Pfrender, M. E., Encalada, S. E. and Lande, R. 2000. Mitochondrial DNA variation, phylogeography and population structure of the Asian elephant. Heredity, 84: 362-72. DOI: $10.1038 / \mathrm{sj} / \mathrm{hdy} / 6886740$.
Gaffaroglu, M. and Yuksel, E. 2004. Karyotype analysis of Cyprinion macrostomus Heckel, 1843 (Pisces: Cyprinidae). Gazi Üniversitesi Kırsehir Egitim Fakultesi Dergisi, 5(2): 235-239.

Hu, Y. D., Pang, H. Z., Li, D. S., Ling, S. S., Lan, D., Wanga, Y., Zhu, Y., Li, D. Y., Rong-Ping, W., Zhang, H. M. and Wang, C. D. 2016. Analysis of the cytochrome c oxidase subunit 1 (COX1) gene reveals the unique evolution of the giant panda. Gene, 592: 303-307. doi: 10.1016/j. gene.2016.07.029. Epub 2016 Jul 13.

Kara, C. and Gunes, H. 2015. Distribution of Cyprinion macrostomum Heckel, 1843 individuals and some morphometric properties in Adiyaman region streams and lakes. Yunus Res. Bull., (4): 13-19.

Kelle, A. 1978. Taxonomic and ecological investigations on fishes living in the Tigris River. Ph. D. Thesis, Dicle University, Diyarbakır.

Kuru, M. 1980. Key to the inland water fishes of Turkey, Part III Hacettepe Bull. Nat. Sci. Eng., 9: 123-133.

Liu, G. and Zhou, L. 2016. Population genetic structure and molecular diversity of the red swamp crayfish in China based on mtDNA COI gene sequences, Mitochondrial DNA Part A, 28(6): 860-866. doi: 10.1080/24701394.2016.1199022.

Ma, C., Cheng, Q., Zhang, Q., Zhuang, P. and Zhao, Y. 2010 Genetic variation of Coilia ectenes (Clupeiformes: Engraulidae) revealed by the complete cytochrome b sequences of mitochondrial DNA. J. Exp. Mar. Bio. Ecol., 385: 14-19.

Nei, M. 1987. Molecular evolutionary genetics. Columbia University Press, New York, 512 pp.

Ortega-Villaizan Romo, M., Suzuki, S., Nakajima, M. and Taniguchi, N. 2006. Genetic evolution of inter individual relatedness for broodstock management of the rare species barfin flounder Verasper moseri using microsatellite DNA markers. Fish. Sci., 72: 33-39. doi.org/10.1111/j.14442906.2006.01113.x.

Parmaksiz, A. and Eksi, E. 2017. Genetic diversity of the cyprinid fish Capoeta trutta (Heckel, 1843) populations from Euphrates and Tigris rivers in Turkey based on mtDNA COI sequences. Indian J. Fish., 64(1): 18-22. DOI: 10.21077/ijf.2017.64.1.62396-03.

Parmaksız, A., Seker, O., Aslan, N. and Oymak, A. 2017 Determination of genetic diversity in Barbus grypus (Heckel, 1843) populations living in Euphrates and Tigris River by using mtDNA COI gene sequences. Yunus Res. Bull., (1): 103-107. DOI: 10.17693/yunusae. v17i26557.284131.

Parmaksiz, A. and Eskici, H. K. 2018. Genetic variation of yellow barbell Carasobarbus luteus (Heckel, 1843) from four populations using mitochondrial DNA COI gene sequences. Appl. Ecol. Environ. Res., 16 (2): 1673-1682.

Sedaghat, S. and Hoseini, S. A. 2012. Length-weight and length-length relationships of Cyprinion macrostomus 
(Heckel, 1843) in Dalaki River Bushehr, in south of Iran. World J. Fish Mar. Sci., 4: 536-538. DOI: 10.5829/idosi. wjfms.2012.04.05.64144.

Tays1, M. R. 2014. Examination of histological and histochemical features of intestines, liver and pancreas in spotted carp (Cyprinion macrostomum Heckel, 1843). Master Thesis, Firat University, Elazig.

Uckun, A. A. and Gokce, D. 2015. Growth and reproduction of Cyprinion macrostomus (Heckel, 1843) and Cyprinion kais (Heckel, 1843) populations in Karakaya Dam Lake (Euphrates River), Turkey. Turk. J. Zool., 39: 685-692. doi:10.3906/zoo-1307-5.

Undar, L., Akpinar, M. A. and Yanikoglu, A. 1990. "Doctor fish” and psoriasis. Lancet, 335: 470-471.
Unlu, E. 1999. A study on the taxonomy and distribution of Cyprinion macrostomus (Heckel, 1843) and Cyprinion kais (Heckel, 1843). In: IX. National Water Products Symposium, Adana, Turkey, p. 688-697.

Xu, Z. H., Chen, J. L., Cheng, D. F., Liu, Y. and Eric, F. 2011. Genetic variation among the geographic population of the Grain aphid, Sitobion avenae (Hemiptera: Aphididae) in China inferred from mitochondrial COI gene sequence. Agr. Sci. China, 10. 1041-1048. DOI: 10.1016/S1671-29 27(11)60092-8.

Ward, R. D. 2000. Genetics in fisheries management. Hydrobiologia, 420: 191-201. DOI: 10.1023/A:10039283 27503. 